\title{
A comparative study on traditional teaching with integrated teaching on II MBBS students
}

\author{
Aluri Anjana Priyanka ${ }^{1}$, Gedela Vasavi ${ }^{2 *}$ \\ ${ }^{1}$ Department of Pathology, ${ }^{2}$ Department of Pharmacology, ASRAMS, Eluru, Andhra Pradesh, India
}

Received: 24 December 2020

Revised: 02 February 2021

Accepted: 04 February 2021

\author{
*Correspondence: \\ Dr. Gedela Vasavi, \\ Email: drvasavi.g@gmail.com
}

Copyright: $\odot$ the author(s), publisher and licensee Medip Academy. This is an open-access article distributed under the terms of the Creative Commons Attribution Non-Commercial License, which permits unrestricted non-commercial use, distribution, and reproduction in any medium, provided the original work is properly cited.

\begin{abstract}
Background: The term integration in education means coordination in the teaching-learning activities to ensure the harmonious functioning of the educational processes.

Methods: Study was conducted in ASRAM medical college. 140 students of II MBBS were randomised into 2 groups. One group was taught by traditional didactic lecture. Other group was taught by integrated teaching along with the pathology department. A post-test questionnaire was given 3 days after the end of each session. The effectiveness of the study was done by assessing both the questionnaires. Feed-back was taken from the students on both types of teaching.

Results: In Integrated teaching group, $12 \%$ got more than $80 \%$ marks, $71 \%$ got more than $60-80 \%$ marks, $11 \%$ students scored 50-60\% marks and $4.7 \%$ students scored less than 50\% marks. In didactic teaching group, $8.95 \%$ scored more than $80 \%$ marks, $45 \%$ students scored $60-80 \%$ marks, $23.88 \%$ students scored $50-60 \%$ marks and $14.92 \%$ students scored less than $50 \%$ marks. In our study, students felt that integrated teaching was of more useful to them. It helped them in understanding of concepts and maintaining interest in topic. They felt that there was a positive interaction which helped them to correlate the two subjects.

Conclusions: This study concludes that integrated teaching is more helpful to students in learning.
\end{abstract}

Keywords: Integrated teaching, Didactic lectures, Education

\section{INTRODUCTION}

Medical schools all over India mainly have lectures as the most widely used teaching and learning methods. Furthermore, the classroom is getting larger due to students numbering more than 100 and their participation remains a challenge. Innovation to use interactive teaching methods in a large classroom is necessary to engage students in a useful way. Integrated teaching is one of the teaching methods introduced in competency based undergraduate curriculum for the Indian medical graduate. Integration is a learning experience that allows the learner to perceive relationships from blocks of knowledge and develop a unified view of its basis and its application. The term integration in education means coordination in the teaching- learning activities to ensure the harmonious functioning of the educational processes. ${ }^{1}$ Integrated thinking offers the capacity to individualize. ${ }^{2}$

Integration concepts framed in GMR (Graduate Medical Education Regulations, 2018):

Temporal co-ordination- timetable is adjusted so that topics within the subjects or disciplines which are related, are scheduled at same time. Sharing- two disciplines may agree to plan and jointly to implement a teaching program. Correlation- the emphasis remains on disciplines or subjects with subject-based courses taking up most of the 
curriculum time. Within this framework, an integrated teaching session or course is introduced in addition to the subject bases teaching. Nesting- the teacher targets within a subject based course- skills relating to subject based course.

The advantages of integrated teaching over traditional lectures are: ${ }^{3}$

Integrated teaching reduces fragmentation of medical courses, prevents repetition and waste of time, students learn to apply their knowledge to clinical practice, promotes interdepartmental collaboration, rationalization of teaching resources

At present the teaching method for II MBBS is didactic lectures.

\section{Aims and objectives}

To introduce integrated teaching to II MBBS students through subjects Pathology and Pharmacology. To study the effectiveness of integrated teaching among students and to get the feedback about the new learning method in comparison to didactic lecture

\section{METHODS}

\section{Study design and setting}

An Institute based interventional randomised study was done in ASRAM medical college, Eluru, Andhra Pradesh. Study period was from August 2019 to September 2019.

\section{Study tools}

The study tools were predesigned pretested structured selfadministered questionnaire containing multiple choice questions- 10 from Pharmacology and 10 from Pathology. The study tools were developed in consultation with 6 experienced teaching staffs, 3 each from 2 disciplines: Namely Pathology and Pharmacology. It was pretested among 30 senior students. Necessary correction and modification were adopted before final data collection. Student feedback forms were designed based on Likert scale.

\section{Study method}

Institutional ethical committee clearance was obtained from IEC, ASRAMS prior to study.

Trained faculty in revised basic course in Medical Education workshop, one from Pathology and one from Pharmacology were selected for the study.

Out of 140 students from 5th semester, who give consent to this study were included in this study. Students who did not wish to take part in this study were excluded. Students were randomised into 2 groups- group A and group B.
Written informed consent was taken from each participant. same topic was taught for both groups but with different modes of teaching. The topic selected was peptic ulcer. It was taught by 2 departments- pathology and pharmacology. Group A students were taught by integration by sharing method on the same day. Group B students were taught by didactic lecture in another week. Feedback of students were taken on following parametersachievement of objective, interest of audience, containment of topic, proper management of time, appropriate use of A-V aids, Interaction with students, Understanding of concepts and overall rating. Feedback was collected from all the students which was designed based on Likert scale. A post-test questionnaire was given 3 days after lecture. The self-administered questionnaire has 10 multiple choice questions for each subjectpathology and pharmacology and each carry 1 mark.

\section{RESULTS}

Out of 140 students, 63 students from Group A and 67 students from group B gave assessment exam and feedback forms. Marks of both the groups were compared by percentages of marks. In Integrated teaching group, $12 \%$ got more than $80 \%$ marks, $71 \%$ got more than $60-80 \%$ marks, $11 \%$ students scored $50-60 \%$ marks and $4.7 \%$ students scored less than $50 \%$ marks. In didactic teaching group, $8.95 \%$ scored more than $80 \%$ marks, $45 \%$ students scored $60-80 \%$ marks, $23.88 \%$ students scored $50-60 \%$ marks and $14.92 \%$ students scored less than $50 \%$ marks (Table 1).

Table 1: Marks scored by students.

\begin{tabular}{|lllll|}
\hline Marks & \multicolumn{2}{c|}{ Group A $(\mathbf{n = 6 3})$} & \multicolumn{2}{c|}{ Group B (n=67) } \\
\hline $\mathbf{8 0 0 \%}$ & 8 & $12 \%$ & 6 & $8.9 \%$ \\
\hline $\mathbf{6 0 - 8 0 \%}$ & 45 & $71.4 \%$ & 35 & $52.23 \%$ \\
\hline $\mathbf{5 0 - 6 0 \%}$ & 7 & $11 \%$ & 16 & $23.88 \%$ \\
\hline $\mathbf{5 0 \%}$ & 3 & $4.7 \%$ & 10 & $14.92 \%$ \\
\hline
\end{tabular}

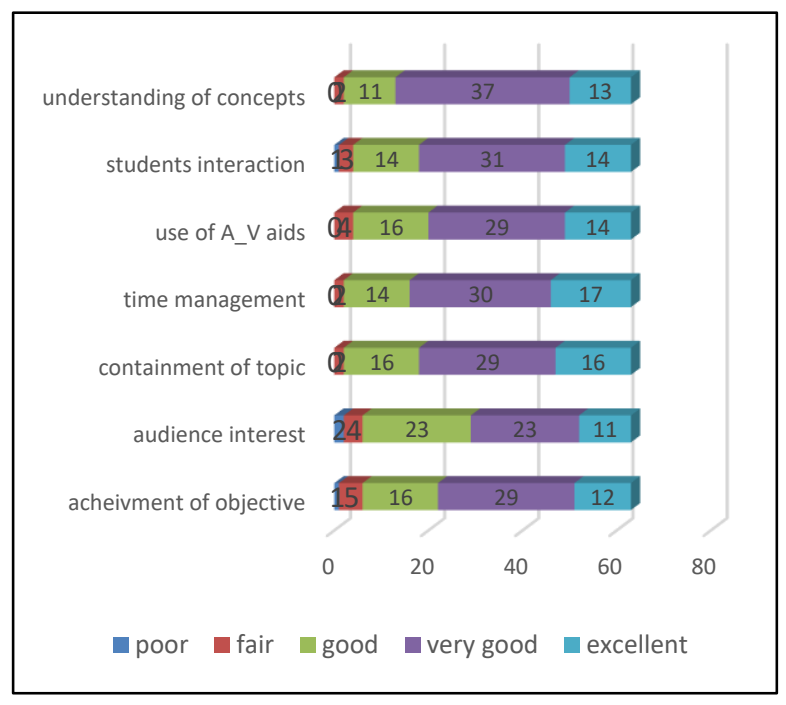

Figure 1: Feedback of integrated teaching group. 
Table 2: Feedback.

\begin{tabular}{|c|c|c|c|c|c|c|}
\hline Feedback questions & Group & Poor & Fair & Good & Very good & Excellent \\
\hline \multirow{2}{*}{ Achievement of objective } & A & 1 & 5 & 16 & 29 & 12 \\
\hline & B & 3 & 12 & 36 & 11 & 5 \\
\hline \multirow{2}{*}{ Interest of audience } & A & 2 & 4 & 23 & 23 & 11 \\
\hline & B & 6 & 16 & 27 & 12 & 6 \\
\hline \multirow{2}{*}{ Containment of topic } & A & 0 & 2 & 16 & 29 & 16 \\
\hline & B & 0 & 5 & 30 & 26 & 6 \\
\hline \multirow{2}{*}{ Proper management of time } & A & 0 & 2 & 14 & 30 & 17 \\
\hline & B & 0 & 11 & 25 & 25 & 6 \\
\hline \multirow{2}{*}{ Appropriate use of A-V aids } & A & 0 & 4 & 16 & 29 & 14 \\
\hline & B & 4 & 15 & 23 & 17 & 8 \\
\hline \multirow{2}{*}{ Interaction with students } & A & 1 & 3 & 14 & 31 & 14 \\
\hline & B & 4 & 8 & 23 & 19 & 12 \\
\hline \multirow{2}{*}{ Understanding of concepts } & A & 0 & 2 & 12 & 35 & 14 \\
\hline & B & 4 & 10 & 23 & 22 & 8 \\
\hline \multirow{2}{*}{ Overall rating } & A & 0 & 2 & 11 & 37 & 13 \\
\hline & B & 0 & 8 & 30 & 18 & 11 \\
\hline
\end{tabular}

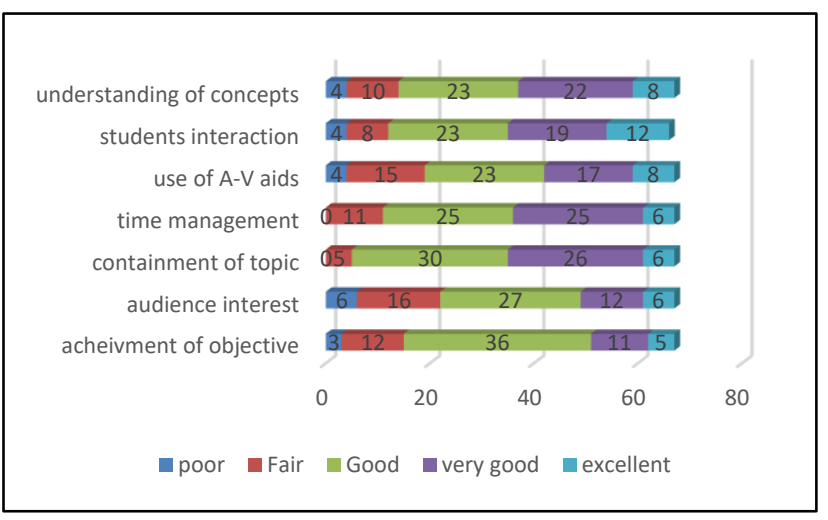

Figure 2: Feedback of group B.

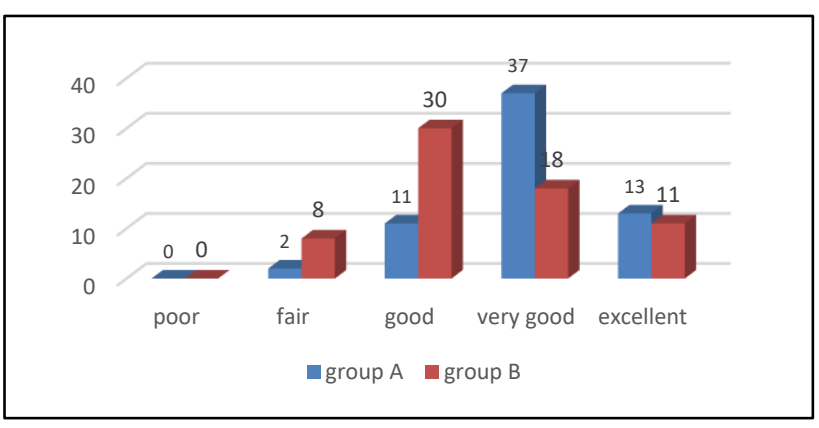

Figure 3: Feedback overall rating.

The feedback was assessed using Likert scale. All the parameters in integrated group got good rating i.e. good, very good and excellent (Figure 1).

\section{DISCUSSION}

According to the competency based undergraduate curriculum for the Indian medical graduate, new teaching methods like self-directed learning, small group discussions, integrated teaching were introduced.
Integration is a learning experience that allows the learner to perceive relationships from blocks of knowledge and develop a unified view of its basis and its application. The GMR 2018 applies the principles to the extent that will retain the strengths of silo - based education and assessment while providing experiences that will allow learners to integrate concepts.

Integration can be done in horizontal way means that two or more departments teaching simultaneously merge their educational identities and vertically means integration between disciplines traditionally taught in the different phases of curriculum. There are four major components in it namely: integration of experience, social integration, integration of knowledge, integration as a curriculum design. ${ }^{4}$

Medical Council of India has adopted an integrated curriculum which de-emphasize compartmentalization of disciplines. $^{5}$

Presently we have non-integrated system of undergraduate curriculum for MBBS which involves mainly didactic lectures. From this study, it was found that integrated teaching was well accepted by students.

$12 \%$ students from integrated teaching group scored more than $80 \%$ marks whereas $8.95 \%$ students from didactic lecture group scored more than $80 \%$ marks. $71 \%$ students form group A scored $60-80 \%$ marks in comparison to Group B where $45 \%$ students scored $60-80 \%$ marks. In group A, $11 \%$ students scored $50-60 \%$ marks and $4.7 \%$ students scored less than $50 \%$ marks. In group B, $23.88 \%$ students scored $50-60 \%$ marks and $14.92 \%$ students scored less than $50 \%$ marks. Similar studies at Seth GS Medical College, Mumbai, Maharasthra by Joglekar et al at MGM's Medical College, Navi Mumbai, India by Kate et al, at Pramukhswami Medical College, Karamsad, Gujarat by Ghosh and Pandya; at Jawaharlal Nehru Medical College, 
Belgaum Karnataka by Dandannavar and at Terna Medical College, Nerul, Navi Mumbai by Nikam and Chopade revealed that the marks obtained by the students who had undergone IT was statistically significantly greater than those who did not. ${ }^{1,6-9}$ But unfortunately we could not compare it in present study.

\section{Students feedback}

In our study, students felt that integrated teaching was of more useful to them. It helped them in understanding of concepts and maintaining interest in topic. They felt that there was a positive interaction which helped them to correlate the two subjects, which was similar to studies by Dandannavar at Karnataka, Nikam and Chopade at Mumbai, Soudarssanane and Sahai at JIPMER, Kadam and Sane at Maharashtra, Kumari et al. at Bangalore, Mahajan et al at Ahmedabad and Rehman et al at Pakistan. ${ }^{8-14}$

\section{CONCLUSION}

The findings and the experience of this study supports the view of other studies that such newer methods of education help to increase teacher-student and teacher-teacher interactions and that Integrated method avoids fragmented manner of teaching where teachers are not aware of what is taught in other subjects. It also removes subject phobia and develops interest in the topic.

\section{ACKNOWLEDGEMENTS}

We are thankful to faculty of Pathology and Pharmacology department for their constant support and encouragement.

\section{Funding: No funding sources}

Conflict of interest: None declared

Ethical approval: The study was approved by the Institutional Ethics Committee

\section{REFERENCES}

1. Barr RB, Tagg J. From teaching to learning - A new paradigm for undergraduate education. Change: Mag High Learn. 1995;27:12-26.

2. Jain BS. Integrated Medical Education: A Must for Homeopathic Colleges and Homeopaths in the Making. Available from: http://www. hpathy.com/ezine/2009july.asp. Last accessed on 29 December, 2016.

3. Nagdeo N. Integrated teaching. J Educ Technol Health Sci. 2014;1:23-6.
4. Beane JA. Curriculum Integration: Designing the Core of Democratic Education. 1 st ed. New York: Teachers College Press. 1997;4.

5. Medical Council of India. General Considerations and Teaching Approach. Salient Features of Regulations on Graduate Medical Education. Ch. 1. New Delhi: Medical Council of India; 1997. Available at https://www.nmc.org.in/wpcontent/uploads/2017/10/ GME_REGULATIONS-1.pdf. Last accessed on 20 November, 2020.

6. Kate MS, Kulkarni UJ, Supu A, Deshmukh YA. Introducing integrated teaching in undergraduate medical curriculum. Int J Pharm Sci Res. 2010;1:1820.

7. Ghosh S. Implementation of Integrated Learning Programme in neurosciences during first year of traditional medical course: perception of students and faculty; BMC Med Educ. 2008;24:8:44.

8. Dandannavar VS. Effect of integrated teaching versus conventional lecturing on MBBS phase I students. Recent Res Sci Technol. 2010;2:40-8.

9. Nikam LH, Chopade SV. Introduction of horizontal integration and comparison with traditional teaching methods in physiology. Int $\mathrm{J}$ Basic Med Sci. 2012;3:143-7.

10. Soudarssanane MB, Sahai A. Innovative integrated teaching of epidemiology. Indian J Community Med. 2007;32:63-4.

11. Kadam S, Sane K. Integrated teaching-tool for reformation of curriculum. Indian J Appl Basic Med Sci. 2013;15:12-9.

12. Kumari KM, Mysorekar VV, Raja S. Students perception about integrated teaching in an undergraduate medical curriculum. J Clin Diagn Res. 2011;5:1256-59.

13. Mahajan DN, Patel DK, Patel DV. Educational innovations/ Programmes for 1 MBBS Batch - 201213 Under Regional Training Centre, Smt. Nhl Municipal Medical College, Ahmedabad. Natl J Integr Res Med. 2013;4:159-63.

14. Rehman R, Iqbal A, Syed S, Kamran A. Evaluation of integrated learning program of undergraduate medical students. Pak J Physiol. 2011;7:37-41.

Cite this article as: Priyanka AA, Vasavi G. A comparative study on traditional teaching with integrated teaching on II MBBS students. Int J Basic Clin Pharmacol 2021;10:227-30. 